\title{
Pengaruh Pertambangan Marmer Terhadap Kondisi Sosial Ekonomi Masyarakat Desa Besole Kecamatan Besuki Kabupaten Tulungagung
}

\author{
Muhammad Bima Sakti 1,*, Achmad Maulana Malik Jamil ${ }^{1}$, Ika Meviana ${ }^{1}$ \\ ${ }^{1}$ Progam Studi Pendidikan Geografi, Universitas Kanjurang, Malang, 65148, Indonesia \\ *Muhammadbimasakti135@gmail.com, maulana3188@unikama.ac.id, meviana@unikama.ac.id
}

Dikirim : 18 Maret 2019

Diterima: 30 Maret 2019

\begin{abstract}
Abstrak Penelitian ini dilatarbelakangi adanya keberadaan industri marmer di Desa Besole Kecamatan Besuki Kabupaten Tulungagung yang tentunya menimbulkan dampak positif. Dampak positifnya seperti penyerapan tenaga kerja, meningkatnya pendapatan, memberikan kesempatan kerja, tersedianya peluang usaha masyarakat. Dampak positif dari keberadaan industri pertambangan marmer akan menimbulkan peruabahan bagi masyarakat baik kondisi sosial maupun ekonomi. Penelitian ini bertujuan untuk mengetahui karateristik fisik dan non fisik dan untuk mengetahui pengaruh bertambangan marmer terhadap kondisi sosial ekonomi masyarakat Desa Besole Kecamatan Besuki Kabupaten Tulungagung Penelitian ini bersifat deskriptif kuantitatif, dengan teknik pengumpulan data yaitu kuisioner, observasi, dokumentasi dan wawancara. Populasi dari penelitian ini adalah masyarakat Desa Besole yang berjumlah 11.528 jiwa. Dalam penelitian ini, penentuan sampel berdasarkan tingkat kepercayaan $85 \%$ dan tingkat kesalahan $15 \%$ yang dikembangkan Slovin sehingga berjumlah 45 responden. Metode penelitian yang digunakan adalah metode survei. Taknik pengambilan sampel yaitu simple random sampling. Instrumen yang digunakan adalah kuisioner, pedoman wawancara, dokumentasi, lembar observasi dan metode analisis data menggunakan regresi linier sederhada dengan pengujian asumsi dasar. Hasil penelitian ini adalah jenis tanah yang ada di Besole adalah tanah alluvial coklat tua kelabuan. Tipe Iklim di Desa Besole secara umum termasuk tipe AW, curah hujan tahunan rata-rata berkisar $>2000 \mathrm{~mm}$. Flora dan fauna ekosistem Desa Besole sama dengan wilayah desa lain. Tingkat pendidikan Masyarakat Di Desa Besole mulai dari tamat SD sampai Perguruan Tinggi ada. Selain itu juga penelitian ini menunjukan bahwa industri pertambangan marmer berpengaruh positif terhadap kondisi sosial ekonomi masyarakat Desa Besole. Pengaruh positifnya adalah industri pertambangan marmer membuka lowongan pekerjaan bagi masyarakat sehingga masyarakat bisa bekerja di pabrik tersebut. Dengan adanya industri pertambangan marmer kondisi sosial ekonomi masyarakat meningkat mulai dari pendapatan. Tingkat pendidikan, membuka kesempatan kerja, menumbuhkan peluang usaha lain.
\end{abstract}

Kata kunci : industri pertambangan marmer, kondisi sosial ekonomi

\section{Pendahuluan}

Kabupaten Tulungagung bagian selatan tapatnya di Desa Besole Kecamtan Besuki Kabupaten Tulungagung memiliki potensi yang cukup kaya dengan sumberdaya alamnya, baik potensi fisik dan potensi non fisiknya. Potensi sumberdaya alam yang sudah dikelola secara besar-bearan adalah potensi pertambangan marmernya. Perusahaan tambang yang melakukan ekplorasi yaitu PT. IMIT (PT. Industri Marmer Indonesia Tulungagung).

PT. IMIT dalam melakukan usaha penambangannya secara serius akan melakukan sinergi antara kepentingan ekonomi (profit), kepentingan lingkungan (social responsibility). Dalam rangka memperoleh manfaat ekonomi dan manfaat sosial yang optimal dengan tetap menjaga keseimbngan lingkungan, maka perlu dikembangkan suatu sistem penambangan yang pada setiap tahap kegiatannya direncanakan dengan matang, sehingga fungsi dan daya lingkungan setelah berakhirnya masa penambangan dapat dipulihkan kembali atau dapat dialihkan untuk peruntukan yang bermanfaat. 
Sektor pertambangan ini merupakan salah satu sektor strategis yang erat dalam penyerapan tenaga kerja, kemiskinan, pengangguran dan membangun ketahanan pangan (Fadhil, 2017). Selain itu, pertambangan di daerah ini semakin marak dengan keluarnya izin usaha pertambangan khususnya marmer, yang dijual dalam bentuk, bongkahan yang sudah diolah terlebih dahulu ke beberapa daerah.

Batu marmer merupakan salah satu sumberdaya alam yang banyak terdapat didunia, batu marmer seringkali kita temukan sebagai batu penghias rumah, sebagai batu yang digunakan untuk lantai, dinding, bukan furnitur seperti meja, bangku dan lain sebagainya. Batu marmer sudah sejak lama digunakan oleh penambang terutama untuk penghias sebuah bangunan. Batu marmer memiliki nilai ekonomis yang cukup tinggi sehingga dengan adanya pertambangan di Desa Besole Kecamatan Besuki Kabupaten Tulungagung, diharapkan dapat meningkatkan meningkatkan sosial ekonomi masyarakat sekitar pertambangan marmer.

Desa Besole merupakan sentra dari pengrajin marmer, karena hampir sebagian besar masyarakat Desa Besole mrupakan pengrajin marmer baik itu sebagai pemilik industri maupun menjadi pekerja. Oleh sebab itu di Desa Besole ini memiliki pengerajin marmer lebih banyak dibandingkan di desa lain di Kecamatan Besuki. Desa ini meupakan penghasil kerajinan marmer dan onix terbesar, dengan hasil produksi sebanyak 24.151 unit per bulan. Marmer, onyx dan batu fosil, deposit marmer berada di Desa Besole Kecamatan Besuki, Desa ngentrong dan Desa Gamping Kecamatan Campurdarat, serta Desa Sukorejo Kecamatan Bandung, jumlah Cadangan kurang lebih 4.322.500 $\mathrm{m}^{3}$ (Agus Trilaksana, 2017).

Berkembangnya usaha pertambangan ini berimplikasi kepada berbagai aspek, diantarannya adalah pemanfaatan lahan pertanian untuk lokasi pertambangan yang menyebabkan berkurangnya luas garapan bagi petani. Selanjutnya tenaga kerja di sektor pertanian, peternakan dan perkebunan lebih memilih melakukan pekerjaan di luar sektornya, termasuk sebagai tenaga kerja pada perusahaan tambang. Perpindahan usaha tambang tenaga kerja tersebut diperkirakan akan menghadapi sejumlah persoalan, baik jangka pendek maupun jangka panjang. Dalam jangka pendek, pengetahuan dan keterampilan yang dimiliki sering kurang dan bahkan tidak relevan dengan jenis pekerjaan diluar sektornya. Oleh sebab itu, tingkat produktivitasnya sebagai tenaga kerja cenderung rendah sehingga gaji atau upah yang diterima relatif kecil. Mereka sering hanya menjadi tenaga kerja atau buruh untuk berbagai jenis pekerjaan, dan mempunyai kedudukan sangat rapuh terhadap pekerjaannya.

Masalah sosial ekonomi merupakan masalah yang masih menghantui masyarakat Indonesia yang tidak pernah ada habisnya, beberapa permasalahan sosial ekonomi itu adalah masih rendahnya tingkat pendidikan, kurang terbukannya kesempatan kerja untuk masyarakat dan tingkat pendapatan yang rendah, hal tersebutlah yang mendorong masyarakat serta perusahaan untuk menggali tambang marmer serta memanfaatkan sumberdaya alam demi membutuhkan keperluan hidup dalam meningkatkan sosial ekonomi salah satu sumberdaya alam yang dapat dimanfaatkan adalah tambang marmer. Tujuan penelitian ini adalah untuk mengetahui kondisi fisik dan non fisik dan untuk mengetahui pengaruh pertambangan marmer terhadap kondisi sosial ekonomi masyarakat Desa Beole Kecamatan Besuki Kabupaten Tulungagung. Berdasarkan latar belakang maka dilakukanlah penelitian "Pengaruh Pertambangan Marmer Terhadap Kondisi Sosial Ekonomi Masyarakat Desa Besole Kecamatan Besuki Kabupaten Tulungagung”.

\section{Metode Penelitian}

Penelitian ini merupakan penelitian deskriptif dengan pendekatan kuantitatif. Penelitian deskriptif merupakan penelitian yang digunkan untuk menggambarkan atau menganalisis suatu hasil penelitian tetapi tidak digunakan untuk membuat kesimpulan. Penelitian 
kuantitatif bertujuan untuk menguji teori, membangun fakta, memberikan deskriptsi statistik dan meramalkan hasilnya.

Populasi dalam penelitian ini adalah masyarakat Desa Besole Kecamatan Besuki Kabupaten Tulungagung dengan jumlah 11.528 orang (BPS, 2017). Teknik penentuan sampel dalam penelitian ini dilakukan dengan menggunakan metode Simple Random Sampling dengan cara sistematik.

Berdasarkan jumlah populasi yang tergolong besar yakni 11.528 maka pengambilan sampel dengan menggunkan rumus slovin dengan taraf signifikan $15 \%$ maka jumlah sampel yang diambil adalah 45 responden.

Instrumen yang digunakan dalam penelitian ini adalah kuisioner, pedoman wawancara, dokumentasi dan lembar observasi sedangkan teknik pengumpulan data dalam penelitian ini adalah kuisoner, wawancara, dokumentasi dan observasi.

Teknik analisis data yang digunakan dalam penelitian ini adalah deskriptif persentase. Setiap item pertanyaan kuisioner di skor untuk selanjutnya di deskripsikan. Penelitian ini menggunkan tabel statistik yang menunjukan angka kisaran teoritis dan rata-rata standar deviasi dengan rumus:

$$
\mathrm{P}=\frac{\mathrm{F}}{\mathrm{N}} \times 100 \%
$$

Keterangan.

P : Deskriptif persentase (\%)

$\mathrm{F}$ : Skor yang diperoleh

$\mathrm{N}$ : Jumlah responden

Sumber: (Sugiyono, 2012)

Uji asumsi dasar yang digunakan dalam penelitian ini adalah uji normalitas dan uji homogenitas. Uji normalitas bertujuan untuk mengetahui apakah distribusi sebuah data mengikuti atau mendekati distribusi normal. Sedangkan uji homogenitas bertujuan untuk mengetahui objek (tiga sampel atau lebih) yang diteliti mempunyai varian yang sama.

Teknik analisis data yang digunakan untuk mengetahui pengaruh pertambangan marmer terhadap kondisi sosial ekonomi masyarakat Desa Besole Kecamatan Besuki Kabupaten Tulungagung. Adapun analisisnya menggunkan analisis statistik dengan metode regresi linier sederhana yang bertujuan untuk mengetahui arah hubungan antara variabel independen (pertambangan marmer) dengan variabel dependen (kondisi sosial ekonomi) apakah positif atau negatif dan untuk mempredisksi nilai variabel. Jika setelah dilakukan uji regresi linier sederhana bernilai positif berarti pertambangan marmer berpengaruh terhadap kondisi sosial ekonomi begitu pula sebaliknya.

\section{Hasil}

Desa Besole merupakan suatu Desa di Kecamatan Besuki Kabupaten Tulungagung dengan luas keseluruhan 577,097 Ha, mempunyai 8 RW dan 44 RT. Wilayah ini berbatasan dengan daerah sebagai berikut: sebelah utara adalah Desa Ngentrong, sebalah selatan adalah Samudra Hindia, sebalah Barat adalah Desa Besuki, sebelah timur adalahj Desa Ngrejo

Jarak dari Desa Besole ke pusat Pemerintahan Kecamatan Besuki 4 km dengan lama jarak tempuh bila menggunkan kendaraan bermotor sekitar 5-10 menit. Sedangkan jarak ke ibukota Kabupaten sekitar $25 \mathrm{~km}$ sebelah selatan ibu kota Kabupaten Tulungagung dengan jarak tempuh sekitar 45-1 jam dengan menggunkan kendaraan bermotor. 
Secara letak wilayahnya, Desa Besole masuk kedalam Kecamatan Besuki Kabupaten Tulungagung Provinsi Jawa Timur. Desa Besole terdiri dari daerah pemukiman penduduk, dikelilingi kawasan industri dan perdagangan dan wilayah pertanian. Untuk menjangkau Desa Besole Kecamatan Besuki ini sangat mudah dengan menggunkan transportasi pribadi maupun umum. Kondisi jalan yang menghubungkan Desa Besole Kecamatan Besuki dengan daerah sekitarnya sangat baik. Adapun pergerakan manusia dan arus barang baik dari luar atau sebaliknya sangat lancar. Wilayah Desa Besole dapat dilihat pada gambar.

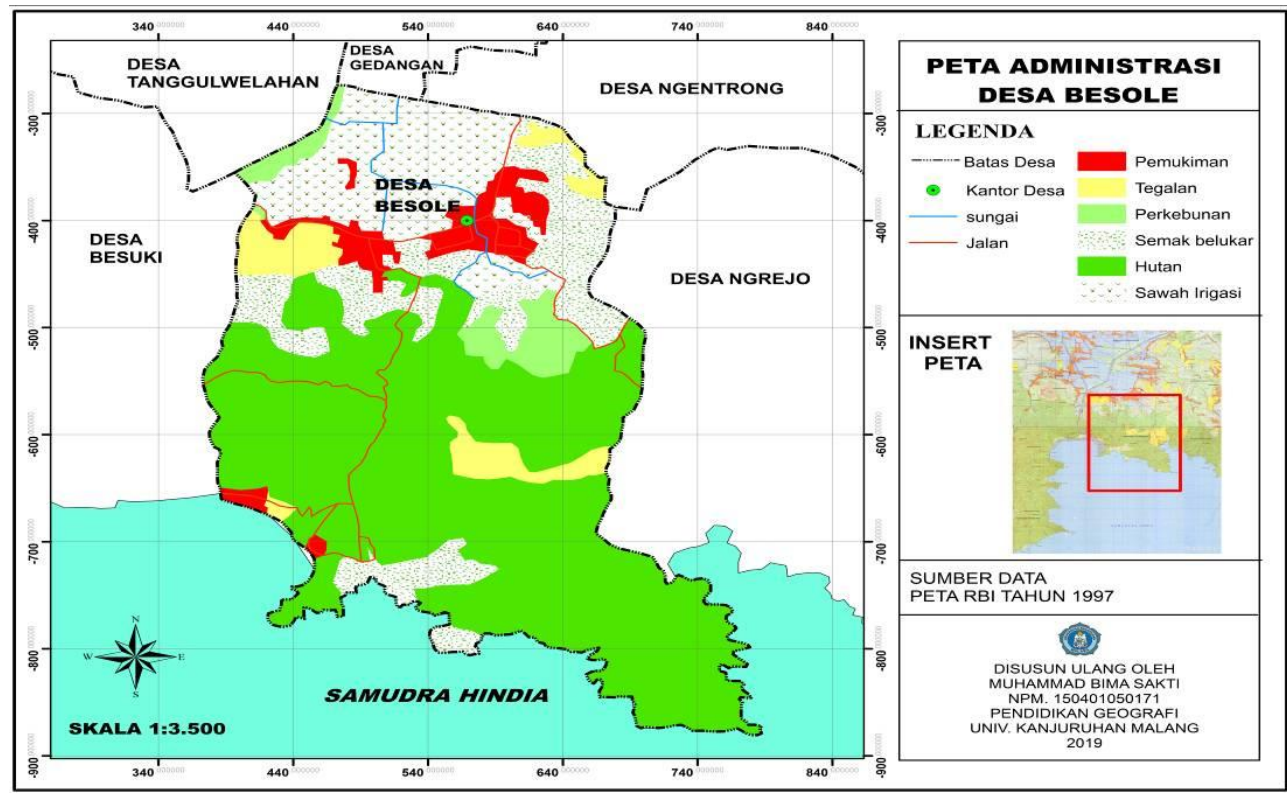

Gambar 1. Peta Administrasi Desa Beole (Peta RBI tahun 1997)

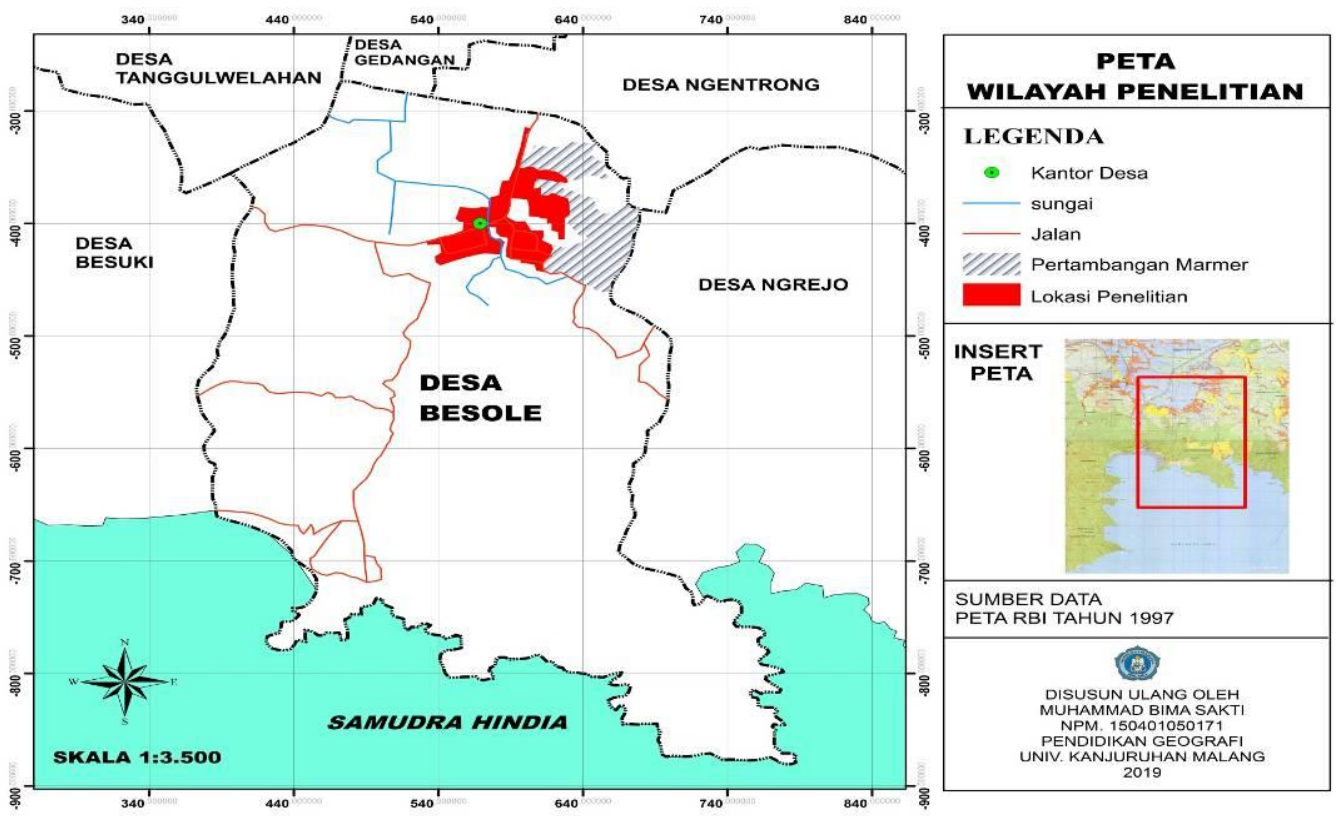

Gambar 2. Peta Wilayah Penelitian (Peta RBI Tahun 1997)

Tujuan dari penggunaan uji normalitas ini untuk mengetahui apakah ada data beraal dari populasi berdistribusi normal atau tidak. Pengujian normalitas ini dengan menggunakan 
uji statistik. Salah satu ujin statistik yang digunkan untuk menguji normalitas residual adalah uji statistik non parametrik Kolmogrof-Sminov.

Tabel 1. One-Sample Kolmogorov-Smirnov Test

\begin{tabular}{cr}
\hline & Unstandardized Residual \\
\hline N & 45 \\
Kolmogorov-Smirnov Z & .892 \\
Asymp. Sig. (2-tailed) & .404 \\
\hline (Sumber: hasil output SPSS data primer yang telah diolah, 2018)
\end{tabular}

Berdasarkan hasil uji normalitas, besarnya nilai Kolmogrov-Smirnov adalah 0,829 dapat diketahui bahwa unstandardized residual memiliki nilai Asymp. Sig > 0,15 dan ini mengartikan bahwa data berdistribusi dengan normal

Berdasarkan uji Homogenitas dapat diketahui kriteria pengujian:

Ho: Jika probabilitas (sig) $>0,15$, maka Ho diterima

Jika probabilitas (sig) $<0,15$, maka Ho ditolak.

Tabel 2. Tes Homogenitas Kondisi Sosial Ekonomi

\begin{tabular}{llll}
\hline Levene Statistic & Sig. & \\
\hline & .559 & .576 \\
\hline
\end{tabular}

(Sumber: hasil output SPSS data primer yang telah diolah, 2018)

Berdasarkan pengujian homogenitas besarnya nilai signifikan adalah 0,576.nilai ini menunjukan nilai sig >

$>\alpha=0,576>0,15$, maka Ho di tolak dan Ha diterima dan data terdistribusi homogen.

Teknik analisis yang digunakan dalam penelitian ini adalah teknik analisis regresi sederhana. Analisis regresi sederhana digunakan sebagai alat analisis statistik karena penelitian ini dirancang untuk meneliti variabel - variabel yang berpengaruh dari variabel independen terhadap variabel dependen.

Tabel 3. Koefisien

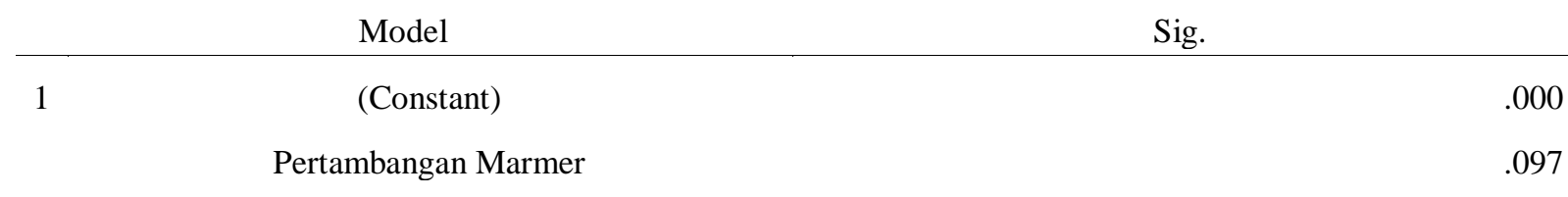

a. Dependent Variable: Kondisi Sosial Ekonomi

(Sumber: hasil output SPSS data primer yang telah diolah, 2018)

Berdasarkan uji regresi linier dapat diketahui nilai probabilitas variabel, bahwa pertambangan marmer berpengaruh terhadap kondisi sosial ekonomi masyarakat Desa Besole Kecamatan Besuki Kabupaten Tulungagung. Nilai konstata sebesar $0.000<0.15$, nilai konstanta positif menunjukan pengaruh positif pertambangan marmer terhadap kondisi sosial ekonomi di Desa Besole Kecamatan Besuki Kabupaten Tulungagung. Pada variabel pertambangan marmer diketahui nilai adalah $0.097<0.15$ dengan demikian ho ditolak dan ha diterima. Artinya variabel pertambangan marmer memberikan pengaruh positif terhdap kondisi sosial ekonomi masyarakat. 
Observasi ini untuk mengetahui fasilitas hidup yang dimiliki oleh masyarakat Desa Besole kecamatan Besuki Kabupetan Tulungagung, hasil observasi sebagai berikut.

Tabel 4. Pengamatan

\begin{tabular}{llll}
\hline \multicolumn{1}{c}{ Aspek yang diamati } & Penilaian & Tidak \\
\hline No & \multicolumn{1}{c}{ Ya } & \\
\hline Keberadaan industrian industri \\
a. Memberikan lowongan pekerjaan \\
Kondisi Sosial Ekonomi \\
a. Bangunan rumah \\
1) Permanen \\
2) Semi permanen \\
b. Alat elektronik & \\
1) TV & $\sqrt{ }$ \\
2) Radio & \\
3) VCD & $\sqrt{ }$ \\
4) Dispenser & $\sqrt{ }$ \\
c. Sarana Komunikasi & $\sqrt{ }$ \\
1) Telepon & \\
2) Hp & $\sqrt{ }$ \\
d. Alat Trasnportasi & $\sqrt{ }$ \\
1) Mobil & $\sqrt{ }$ \\
2) Motor & $\sqrt{ }$ \\
3) Sepeda & $\sqrt{ }$
\end{tabular}

(Sumber: Hasil Observasi Lapangan 2018 Desa Besole)

Berdasarkan hasil observasi Kondisi sosial ekonomi masyarakat Desa Besole dengan melihat tempat tinggal atau rumah masyarakat dengan kondisi bangunan rumah masyarakat yang hampir semua sudah permanen. Masyarakatnya sebgaian sudah dapat memenuhi kebutuhan hidupnya akan barang - barang elektronik contohnya, TV, VCD, radio. Sarana komunikasi seperti hp. Tetapi untuk alat tranportasi kebanyakan masyarakat Desa Beole hanya memiliki motor dan sepeda. Sedangkan untuk mobil hanya sebagian warga yang memilikinya. Maka dapat disimpulkan bahwa kondisi sosial ekonomi masyarakat Desa Besole baik. Karena dengan adanya perolehan pendapatan masyarakat sebgaian besar dapat memenuhi kebutuhannya.

\section{Pembahasan}

Desa Besole merupakan desa yang berada pada rangkaian formasi pegunungan sewu sehingga desa ini beda dengan desa lain. Dengan adanya rangkaian formasi pegunangan sewu yang menyebabkan desa ini termasuk daerah karst, sangat jelas terlihat pada desa ini ditemukan batuan kapur pada batuan permukaan. Banyak terdapat gua gua kapur dan gunung kapur yang ditambang oleh masyarakat berupa marmer dan gamping.

Desa Besole mmemiliki jenis tanah alluvial coklat tua kelabuan dengan kedalaman tanah mencapai $90 \mathrm{~cm}$ dan memiliki tekstur sedang. Tekstur tanah berpengaruh terhadap pengelolaan tanah dan pertumbuhan tanaman. Sifat tekstur tanah berhubungan erat dengan kandungan udaran dalam rongga tanah (porositas), peresapan (permeabilitas), serta daya menyimpan air dan unsur hara lainnya (mudah tidaknya tererosi). Tekatur tanah ditentukan oleh perbandingan partikel pasir, debu dan liat. Tanah bertekstur halus lebih dalam reaksi kimianya dari pada tanah bertekstur kasar. Melihat kondisi tekstur tanah yang terdapat pada Desa Besole yaitu tergolong sangat baik untuk digunakan sebagai pertanian Hal ini sesuai 
karakteristik tanah aluvial yaitu warna tanah kecoklatan, tektur tanah liat atau liat berpasir ( Sari, 2015).

Tipe Iklim di Desa Besole secara umum termasuk tipe AW, yang merupakan ikilm hujan tropis bermusim. Tipe hujan dicirikan oleh turunannya hujan bermusim (bulan OktoberMaret), dan adanya musim kemarau pada bulan April-September. Suhu Tertinggi pada Desa Besole mencapai $34^{\circ}$ dan suhu terendah mencapai $22^{\circ}$. Untuk kelembaban udara berkisar 74$77 \%$ dan curah hujan tahunan rata-rata berkisar $>2000 \mathrm{~mm}$. (Daljoeni, 2014).

Flora ekosistem Desa Besole memiliki fungsi ekonomis maupun ekologis yang sangat tinggi, baik dalam bentuk herbal, perdu maupun pohon. Tanaman yang ada di Desa Besole adalah pohon jati, pohon kelapa, angsana, kare payung peneduh, Flamboyan, Trembesi, mahoni, palem raja, almanda, bunga kana, rumput gajahan, cares, glodok dan lain sebagainya. Sedangkan fauna yang ada di Desa Besole yaitu, anjing, ayam kampung, bebek, burung merpati, domba, kambing, kelinci, kambing, kucung, kerbau, sapi dan lain lain. (Badan Lingkungan Hidup Kabupaten Tulungagung)

Tingkat pendidikan Masyarakat Di Desa Besole Kecamatan Besuki Kabupaten Tulungagung mulai dari tamat SD sampai Perguruan Tinggi ada. Hal tersebut menunjukan bahwa masyarakat Desa Besole Kecamatan Besuki Kabupaten Tulungagung sudah memiliki atau lulus jalur pendidikan formal antara lain SD, SMP, SMA, Perguruan Tinggi. Hal ini sesuai dengan Undang-Undang Republik Indonesia nomor 20 tahun 2003 tentang sistem pendidikan nasional bahwa jenjang pendidikan formal terdiri atas pendidikan dasar, pendidikan menengah, pendidikan tinggi. (Undang-Undang Nomor 20 Tahun 2003)

Hasil penelitian ini menunjukan bahwa terdapat pengaruh dari keberadaan industri pertambangan marmer terhadap kondisi sosial ekonomi masyarakat Desa Besole Kecamatan Besuki Kabupaten Tulungagung. Berdasarkan uji regresi diketahui bahwa signifikansi sebesar 0.097 atau 0.097 < dari 0.15 yang artinya industri pertambangan marmer berpengaruh positif terhadap kondisi sosial ekonomi masyarakat.

Berdasarkan hasil analisis industri pertambangan marmer berpengaruh terhadap kondisi sosial ekonomi masyarakat. Dengan adanya Industri pertambangan marmer yang berada ditengah tengah masyarakat Desa Besole memberikan lowongan pekerjaan, selain memberikan lowongan pekerjaan pabrik juga memberikan limbah sehingga limbah tersebut bisa diolah lagi oleh masyarakat. Hal tersebut direspon positif oleh masyarakat Desa Besole Kecamatan Besuki Kabupaten Tulungagung, oleh karena itu dengan banyaknya warga sekitar yang bekerja di industri petambangan marmer dapat mengurai pengagguran.

Tingkat pendidikan Responden sebagian besar memiliki pendidikan terkahir SMA/SMK sebanyak 28 orang, pendidikan terakhir SMP sebanyak 9 orang, pendidikan terakhir SD sebanyak 8 orang, dan pendidikan terakhir perguruan Tinggi sebanyak 0 orang. Hal tersebut menunjukan bahwa responden sudah memiliki atau lulus jalur pendidikan formal antara lain SD, SMP, SMA, Perguruan Tinggi. Hal ini sesuai dengan Undang-Undang Republik Indonesia nomor 20 tahun 2003 tentang sistem pendidikan nasional bahwa jenjang pendidikan formal terdiri atas pendidikan dasar, pendidikan menengah, pendidikan tinggi. (Undang-Undang Nomor 20 Tahun 2003)

Dikaitkan dengan keberadaan industri pertambangan marmer terhadap kondisi sosial ekonomi dari tingkat pendidikan masyarakat di Desa Besole antara sebelum dan sesudah adanya industri pertambangan marmer baik - baik saja, yang membedakan adalah setelah adanya industri pertambangan marmer tingkat pendidikan meningkat. Dengan adanya industri pertambangan marmer mempengaruhi tingkat pendidikan masyarakat, karena sebagian besar masyarakat memiliki pendapatan yang cukup besar sehingga dapat menyekolahkan anaknya sampai perguruan tinggi. Selain itu juga masyarakat yang bersekolah tinggi atau 
berpendidikan tinggi dengan alasan yang lebih pintar dan lebih sukses bukan ingin bekerja di industri peertambangan marmer atau pabrik lainnya.

Mata pencaharian yang banyak dilakukan oleh responden yaitu buruh atau karyawan industri pertambangan marmer yang merupakan tanggungjawab untuk memenuhi kebutuhannya sendiri. Selain itu ada responden yang bekerja sebagai wiraswasta, wirausaha maupun PNS. Hal ini menunjukan bahwa responden memiliki tanggungjawab untuk memenuhi kebutuhannya masing-masing. . Hal ini sesuai dengan pengrtian mata pencaharian yang merupakan sekumpulan tugas dan tanggungjawab yang akan, sedang dan telah dikerjakan dalam kurun waktu tertentu (Sastrohardiwiryo, 2003)

Keberadaan industri pertambangan marmer tentunya memberikan pengaruh pula pada pendapatan masyarakat, karena pendapatan seseorang dapat dilihat dari mata pencahariannya. Sebagian besar masayarakat Desa Besole sebelum adanya industri marmer bermata pencaharian sebagai petani dan nelayan, akan tetapi dengan adanya industri pertambangan marmer sebagian masyarakat bekerja di industri tersebut. Bagi sebagian masyarakat pendapatannya mengalami peningkatan. Selain bekerja di industri pertambangan marmer, masyarakat mendapat pendapatan di bidang lain seperti membuka warung, menjual limbah pabrik, tambal ban, bengkel dan usaha lainnya. Pendapatan tersebut merupakan dari hasil atau usaha mereka untuk mendapatkan uang. Hal ini sesuai dengan Kamus Besar Bahasa Indonesia tentang Pendapatan (KBBI, 2018).

Adanya industri pertambangan marmer otomatis akan membuka kesempatan kerja. Sebanyak 26 responden menyatakan bahwa dengan adanya industri marmer akan membuka kesempatan kerja bagi masyarakat. Industri pertambangan marmer membuka kesempatan kerja sesuai yang dibutuhkan pabrik misalnya pengerajin marmer, buruh angkut, buruh potong marmer, satpam dan lain sebaginya. Hal ini sesuai dengan pengertian keadaan semua orang yang bersedia dan dapat bekerja sesuai dengan pernyataan tertentu dengan bidang yang diperlukan untuk setiap produksi dan proses produksi (Syaifudin dalam Purwantoro, 2010).

Keberadaan industri marmer juga dapat menumbuhkan peluang usaha lain bagi masyarakat sekitar. Sebnayak 27 responden mengakatan bahwa dengan adanya industri marmer akan menumbuhkan peluang usaha lain bagi masayarakat Desa Besole Kecamatan Besuki Kabupaten Tulungagung. Masyarakat memanfaatkan adanya industri pertambangan marmer untuk membuka usaha seperti membuka warung makan, membuka toko, membuka tambal ban, tukang ojek dan lain lain. Hal ini sesuai dengan pengertian kesempatan yang didapatkan seseorang dengan mengendalikan diri dan memanfaatkan bebagai kesempatan baik tu peluang usaha yang bisa dan siap kita ambil (Aris, 2009)

Berdasarkan hasil observasi kondisi sosial ekonomi masyarakat Desa Besole dengan melihat kondisi tempat tinggal atau rumah masyarakat dengan bangunan rumah yang sudah permanen. Masyarakatnya sebagian besar sudah bisa memenuhi kebutuhan hidupnya seperti alat elektronik, sarana komunikasi dan alat transportasi seperti TV, VCD, radio, hp, motor, sepeda dan mobil, beda halnya sebelum adanya industri pertambangan marmer hanya sebgaian masyarakat saja yang memiliki fasilitas hidup. Maka dapat disimpulkan bahwa kondisi sosial ekonomi masyarakat Desa Besole sudah baik. Karena dengan adanya perolehan pendapatan masyarakat akibat dari adanya industri pertmabangan marmer mereka dapat memenuhi kebutuhannya.

\section{Kesimpulan}

Jenis tanah yang ada di Besole adalah tanah alluvial coklat tua kelabuan dengan kedalaman tanah mencapai $90 \mathrm{~cm}$ dan memiliki tekstur sedang. Tipe Iklim di Desa Besole secara umum termasuk tipe AW, yang merupakan ikilm hujan tropis bermusim. Suhu 
Tertinggi pada Desa Besole mencapai $34^{\circ}$ dan suhu terendah mencapai $22^{\circ}$. Untuk kelembaban udara berkisar 74-77\% dan curah hujan tahunan rata-rata berkisar $>2000 \mathrm{~mm}$. Flora ekosistem Desa Besole memiliki fungsi ekonomis maupun ekologis yang sangat tinggi, baik dalam bentuk herbal, perdu maupun pohon. Sedangkan fauna yang ada di Desa Besole yaitu, anjing, ayam kampung, bebek, burung merpati, domba, kambing, kelinci, kucing, kerbau, sapi dan lain lain. Tingkat pendidikan Masyarakat Di Desa Besole Kecamatan Besuki Kabupaten Tulungagung mulai dari tamat SD sampai Perguruan Tinggi ada.

\section{Daftar Rujukan}

Aris, N.B, 2009 Peluang Usaha, (Web.id/peluangusaha), diakses 15 Oktober 2018

BLH. 2012. Flora Dan Fauna Kabupetan Tulungagung. (Online),

(https://issuu.com/blhtulungagung/docs/buuku_slhd_t.agung_2012), diakses 16 Oktober 2018.

BPS. 2018. Pengertian Pendapatan. (Online). (https://www.bps.go.id/istilah:/index.html), Diakses 18 oktober 2018

Daldjoeni. 2014. Pokok pokok klimatologi. Yogyakarta. Ombak.

Fadhil, Fachri. 2017. Pengaruh Pertambangan Nikel Terhadap Kondisi Sosial Ekonomi Masyarakat Kecamatan Tinanggae Kabupaten Konawe Selatan. Skripsi Fakultas Ilmu Dan Teknologi Kebumian Progam Studi Teknik Pertambangan Universitas Hala Oleo Kendari. (Online). (http://sitedi.uho.ac.id/), diakses 15 Oktober 2018.

Nawawi, Imam, 2014, Pengaruh Keberadaan Industri Terhadap Kondisi Sosial Ekonomi Dan Budaya Masyarakat. Skripsi Progam Studi Sosiologi Fakultas Pendidikan Ilmu Pengetahuan Sosial Universitas Pendidikan Indonesia Bandung. (Online). (http://ejournal.upi.edu/index.php/sosietas/article/download/1528/1054), diakses 22 Oktober 2018.

Sari, Ifana, Yuli. 2015. Geografi tanah. Malang. Pohon ilmu.

Siregar, syofian. Statistik Parametrik Untuk Penelitian Kuantitatif Dilengkapi Dengan Perhitungan Manual dan Aplikasi SPSS Versi 17. Jakarta: PT Bumi Aksara 2013. (Online). ((https://www.belbuk.com/statistik-parametrik-untuk-penelitian-kuantitatifdilengkapi-dengan-perhitungan-manual-dan-aplikasi-spss-versi-17-p-29816.html), diakses 20 Oktober 2018.

Sugiyono. 2010. Metode Penelitian Pendidikan pendektan kuantitatif, kualitatif, dan $R \& D$. Bandung. Alfabeta.

Ulan Ria, Ike. 2017. Pengaruh Keberadaan Indistri Terhadap Kondisi Sosial Ekonomi Masyarakat Di Desa Telaga Kecamatan Cikupa Kabupaten Tangerang (Studi PT. Rinnai). Skripsi Fakultas Ilmu Tarbiyah dan Keguruan Jurusan Pendidikan Ilmu Sosial Universitas Islam Negeri Syarif Hidayatullah Jakarta. (Online). (http://repository.uinjkt.ac.id/), diakses tanggal 20 Oktober 2018.

Undang-Undang Nomor 20 Tahun 2003 pasal 1 (ayat 1 dan 4) Tentang Sistem Pendidikan Nasional. (Online). (http://kelembagaan.ristekdikti.go.id/wpcontent/uploads/2016/08/UU_no_20_th_2003.pdf), diakses 25 Oktober 2018 